\title{
Anthropogenic Drivers of Mangrove Loss and Associated Carbon Emissions in South Sumatra, Indonesia
}

\author{
Syaiful Eddy ${ }^{1}$ (D), Noril Milantara ${ }^{2}$ (D) Sigit D. Sasmito ${ }^{3,4}$, Tadashi Kajita ${ }^{5}$ and Mohammad Basyuni ${ }^{6,7, *(\mathbb{D})}$ \\ 1 Department of Biology, Faculty of Natural Sciences and Technology, Universitas PGRI Palembang, Jl. Jend. \\ A. Yani, 9/10 Ulu, Palembang 30251, Indonesia; syaifuleddy@univpgri-palembang.ac.id \\ 2 Faculty of Forestry, Universitas Muhammadiyah Sumatera Barat, Jl. Pasir Kandang, No. 4 Koto Tangah, \\ Kota Padang 25172, Indonesia; milantara@umsb.ac.id \\ 3 NUS Environmental Research Institute, National University of Singapore, 21 Lower Kent Ridge Road, \\ Singapore 119077, Singapore; eriv111@nus.edu.sg \\ 4 Department of Geography, National University of Singapore, Singapore 117411, Singapore \\ 5 Iriomote Station, Tropical Biosphere Research Center, University of the Ryukyus, Taketomi, \\ Okinawa 907-1541, Japan; kajita@mail.ryudai.jp \\ 6 Department of Forestry, Faculty of Forestry, Universitas Sumatera Utara, Jl. Tri Dharma Ujung No. 1, \\ Medan 20155, Indonesia \\ 7 Center of Excellence for Mangrove, Universitas Sumatera Utara, Medan 20155, Indonesia \\ * Correspondence: m.basyuni@usu.ac.id
}

check for updates

Citation: Eddy, S.; Milantara, N.; Sasmito, S.D.; Kajita, T.; Basyuni, M. Anthropogenic Drivers of Mangrove Loss and Associated Carbon Emissions in South Sumatra, Indonesia. Forests 2021, 12, 187. https://doi.org/10.3390/f12020187

Academic Editors: Victor H.

Rivera-Monroy, Xosé Lois Otero-Pérez, Jorge Lopez-Portillo and Tiago Osorio Ferreira

Received: 4 December 2020

Accepted: 3 February 2021

Published: 7 February 2021

Publisher's Note: MDPI stays neutral with regard to jurisdictional claims in published maps and institutional affiliations.

Copyright: (c) 2021 by the authors. Licensee MDPI, Basel, Switzerland. This article is an open access article distributed under the terms and conditions of the Creative Commons Attribution (CC BY) license (https:/ / creativecommons.org/licenses/by/ $4.0 /)$.

\begin{abstract}
The Air Telang Protected Forest (ATPF) is one of the most dynamic and essential coastal forest landscapes in South Sumatra, Indonesia, because of its location between multiple river outlets, including the Musi catchment-Sumatra's largest and most dense lowland catchment area. While most ATPF areas are covered by mangroves, these areas have been experiencing severe anthropogenicdriven degradation and conversion. This study aims to evaluate land cover changes and associated carbon emissions in the ATPF over a 35-year period (1985-2020) by utilizing the available Landsat and Sentinel imagery from 1985, 2000, and 2020. Throughout the analysis period, we observed $63 \%$ (from 10,886 to 4059 ha) primary and secondary forest loss due to land use change. We identified three primary anthropogenic activities driving these losses, namely, land clearing for plantations and agriculture (3693 ha), coconut plantations (3315 ha), aquaculture (245 ha). We estimated that the largest carbon emissions were caused by coconut plantation conversion, with total carbon emissions of approximately $14.14 \mathrm{Mt} \mathrm{CO}_{2}$-eq. These amounts were almost 4 and 21 times higher than emissions from land clearing and aquaculture, respectively, as substantial soil carbon loss occurs once mangroves get transformed into coconut plantations. While coconut plantation expansion on mangroves could generate significant carbon stock losses and cleared forest become the primary candidate for restoration, our dataset could be useful for future land-based emission reduction policy intervention at a subnational level. Ultimately, our findings have direct implications for current national climate policies, through low carbon development strategies and emission reductions from the land use sector for 2030, as outlined in the Nationally Determined Contributions (NDCs).
\end{abstract}

Keywords: coastal forest; land cover change; mangrove forest; deforestation; remote sensing

\section{Introduction}

Mangrove forests are found in intertidal regions along tropical and subtropical coastlines [1] between $30^{\circ} \mathrm{N}$ and $30^{\circ} \mathrm{S}$ latitude [2,3]. These forests grow along muddy beaches with a low hydrodynamic intensity, especially in areas with expansive river estuaries and deltas where sediments are continuously supplied by upland catchments. The macroecological structure and species composition of mangrove forests are influenced by biogeographic, climate, and hydro-geomorphic factors [4]. Naturally, each mangrove species has its own level of tolerance to salinity concentration. This has implications for the zonation of a distinct species, from seaward to landward (microscale) factors, and hydro-geomorphic factors 
(macroscale) [5]. Species zonation is also driven by species tolerance toward tide-driven flooding frequency [4].

Mangrove forests provide valuable ecosystem services, which include preventing coastal erosion, providing habitats for various species, regulating nutrients, primary productivity, protecting coastal communities from extreme weather, and nature-based carbon storage for climate change mitigation [6-13]. However, the delivery of these ecosystem services is threatened by anthropogenic pressures, such as deforestation, forest conversion, and sea-level rise, leading to substantial mangrove degradation [3,14-18].

With more than 17,500 islands and $95.181 \mathrm{~km}$ of coastline, Indonesia has the largest mangrove forest in the world, covering an area of about 3.2 million ha $[19,20]$. The Air Telang Protected Forest (ATPF) is one of the coastal protection forests in the South Sumatra Province, which is home to about 12,660 ha of mangroves. However, some areas of this forest have been degraded because of land-use conversion for coconut and oil palm plantations, fishponds, agricultural land, ports, and settlements [21]. One of the degradation impacts includes the decline of mangrove species diversity [22]. Some other impacts require further assessment in order to improve current land management in this area and to minimize mangrove loss in the future, specifically as mangroves are being recognized as important ecosystems for the nature-based mitigation of the impacts of global climate change in coastal areas [23]. Anthropogenic disturbances have changed some of the ATPF forest cover in the past, which has resulted in a decline of ATPF function, specifically protecting valuable forest habitat and biodiversity. Restoration efforts are required in order to reverse the loss of the mangrove forest, protect coastlines, and restore biodiversity and fisheries' productivity [24]. Several degraded areas have been restored through natural restoration projects led by the government and local communities, but these land cover dynamics have never been documented.

To evaluate historical drivers of mangrove area loss and their associated carbon emissions in ATPF, we analyzed, identified, and quantified the area of mangrove forest cover change over 35 years during 1985-2020, using a remote sensing technique. To achieve this study's aim, we formulated the following three objectives: (1) to produce a land cover map of ATPF for the years 1985, 2000, and 2020; (2) to quantify and identify the land cover changes for each land cover class between the 1985-2020 periods; and (3) to estimate the carbon emissions generated by the identified mangrove loss drivers. Remote sensing offers a cost-efficient approach and beneficial outcomes, specifically to reconstruct historical mangrove cover change [25]. It could generate accurate, reliable, and efficient spatial information important for mangrove monitoring and for examining the ecosystem response to anthropogenic drivers and environmental changes $[26,27]$. The findings from this study may be used by the subnational government for implementing low carbon development under the land sector, including conservation-based management improvement, and would also be useful to guide future restoration efforts [28]. This is in line with the current national climate policy interests, in which the Government of Indonesia will be incorporating the mangrove ecosystem as part of the nature-based climate solution from the land-use sector.

\section{Materials and Methods}

\subsection{Description of the Study Area}

This research was conducted in the Air Telang Protected Forest (ATPF), a coastal forest landscape dominated by mangroves with an area of 12,660 ha, located in South Sumatra Province, Indonesia (Figure 1). According to the literature [22], the ATPF is covered by true and associated mangroves dominated by Nypa fruticans, Rhizophora apiculate, and Acrostichum aureum. 

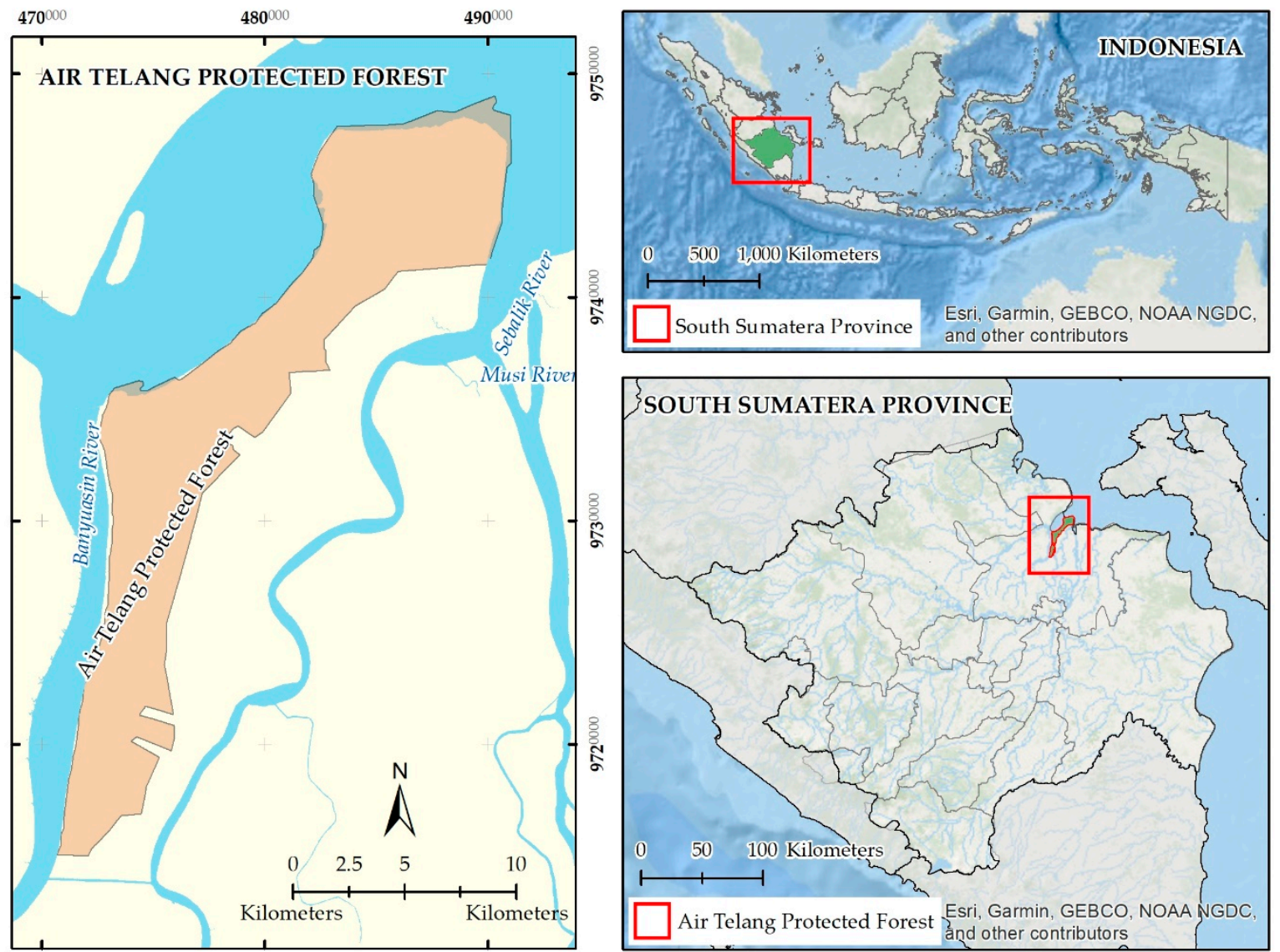

Figure 1. Map of research locations at the Air Telang Protected Forest (ATPF) in South Sumatra Province, Indonesia (red color). Map coordinate system: UTM (Universal Transverse Mercator) projection, zone 48 S, datum WGS (WGS (world geodetic system) 1984 .

\subsection{Data Collection}

The imagery data were obtained from Landsat 5 imagery for the years 1985 and 2000, and Sentinel-2 for the year 2020 (see Table 1 for the detailed satellite image information used in this study). Forestry thematic maps and relevant land cover maps obtained from the Provincial Forestry Service were used to support land cover classification and to improve the accuracy of the classification results. Additionally, a series of land cover ground checks were conducted in 2000 for primary mangrove forests, secondary mangrove forests, coconut plantations, fishponds, and open areas, as summarized in Table 2. The collected coordinates of each land cover were used for training points during the classification analysis and accuracy test. Coordinates were collected using a handheld Geographical Positioning System (GPS), as shown in Table 2. The pictures of each land use field condition obtained during the ground check fieldwork are presented and summarized in Figure 2.

Table 1. Specifications of the Landsat image data used.

\begin{tabular}{ccccc}
\hline Data Type & Bands Kind & Resolution (m) & $\begin{array}{c}\text { Date of } \\
\text { Acquisition }\end{array}$ & Source \\
\hline Landsat 5 TM & RGB 543 & 30 & 21 October 1985 & USGS glovis \\
Landsat 5 TM & RGB 543 & 30 & 19 August 2000 & USGS glovis \\
Sentinel-2 & RGB 654 & 10 & 20 April 2020 & USGS glovis \\
\hline
\end{tabular}


Table 2. The coordinates of the ground check results using a Geographical Positioning System (GPS).

\begin{tabular}{cccc}
\hline No. & Latitude & Longitude & Actual-Condition \\
\hline 1 & $2^{\circ} 32^{\prime} 0.874^{\prime \prime} \mathrm{S}$ & $104^{\circ} 45^{\prime} 52.912^{\prime \prime} \mathrm{E}$ & Secondary Forest \\
2 & $2^{\circ} 16^{\prime} 42.162^{\prime \prime} \mathrm{S}$ & $104^{\circ} 54^{\prime} 22.317^{\prime \prime} \mathrm{E}$ & Secondary Forest \\
3 & $2^{\circ} 20^{\prime} 36.549^{\prime \prime} \mathrm{S}$ & $104^{\circ} 51^{\prime} 36.003^{\prime \prime} \mathrm{E}$ & Secondary Forest \\
4 & $2^{\circ} 22^{\prime} 31.778^{\prime \prime} \mathrm{S}$ & $104^{\circ} 48^{\prime} 15.035^{\prime \prime} \mathrm{E}$ & Primary Forest \\
5 & $2^{\circ} 17^{\prime} 20.364^{\prime \prime} \mathrm{S}$ & $104^{\circ} 52^{\prime} 15.878^{\prime \prime} \mathrm{E}$ & Primary Forest \\
6 & $2^{\circ} 19^{\prime} 55.811^{\prime \prime} \mathrm{S}$ & $104^{\circ} 50^{\prime} 45.469^{\prime \prime} \mathrm{E}$ & Primary Forest \\
7 & $2^{\circ} 33^{\prime} 15.545^{\prime \prime} \mathrm{S}$ & $104^{\circ} 45^{\prime} 39.05^{\prime \prime} \mathrm{E}$ & Coconut Plantation \\
8 & $2^{\circ} 24^{\prime} 21.234^{\prime \prime} \mathrm{S}$ & $104^{\circ} 48^{\prime} 54.87^{\prime \prime} \mathrm{E}$ & Coconut Plantation \\
9 & $2^{\circ} 31^{\prime} 0.584^{\prime \prime} \mathrm{S}$ & $104^{\circ} 45^{\prime} 58.816^{\prime \prime} \mathrm{E}$ & Coconut Plantation \\
10 & $2^{\circ} 23^{\prime} 23.353^{\prime \prime} \mathrm{S}$ & $104^{\circ} 48^{\prime} 21.203^{\prime \prime} \mathrm{E}$ & Fishpond \\
11 & $2^{\circ} 21^{\prime} 59.763^{\prime \prime} \mathrm{S}$ & $104^{\circ} 50^{\prime} 28.207^{\prime \prime} \mathrm{E}$ & Fishpond \\
12 & $2^{\circ} 23^{\prime} 35.178^{\prime \prime} \mathrm{S}$ & $104^{\circ} 47^{\prime} 53.384^{\prime \prime} \mathrm{E}$ & Fishpond \\
13 & $2^{\circ} 30^{\prime} 15.817^{\prime \prime} \mathrm{S}$ & $104^{\circ} 46^{\prime} 23.389^{\prime \prime} \mathrm{E}$ & Open Area \\
14 & $2^{\circ} 21^{\prime} 17.159^{\prime \prime} \mathrm{S}$ & $104^{\circ} 50^{\prime} 30.569^{\prime \prime} \mathrm{E}$ & Open Area \\
15 & $2^{\circ} 20^{\prime} 2.949^{\prime \prime} \mathrm{S}$ & $104^{\circ} 52^{\prime} 41.706^{\prime \prime} \mathrm{E}$ & Open Area \\
16 & $2^{\circ} 16^{\prime} 36.561^{\prime \prime} \mathrm{S}$ & $104^{\circ} 53^{\prime} 59.572^{\prime \prime} \mathrm{E}$ & Water Body \\
17 & $2^{\circ} 17^{\prime} 1.211^{\prime \prime} \mathrm{S}$ & $104^{\circ} 51^{\prime} 59.945^{\prime \prime} \mathrm{E}$ & Water Body \\
18 & $2^{\circ} 17^{\prime} 4.611^{\prime \prime} \mathrm{S}$ & $104^{\circ} 55^{\prime} 2.086^{\prime \prime} \mathrm{E}$ & Water Body \\
\hline
\end{tabular}

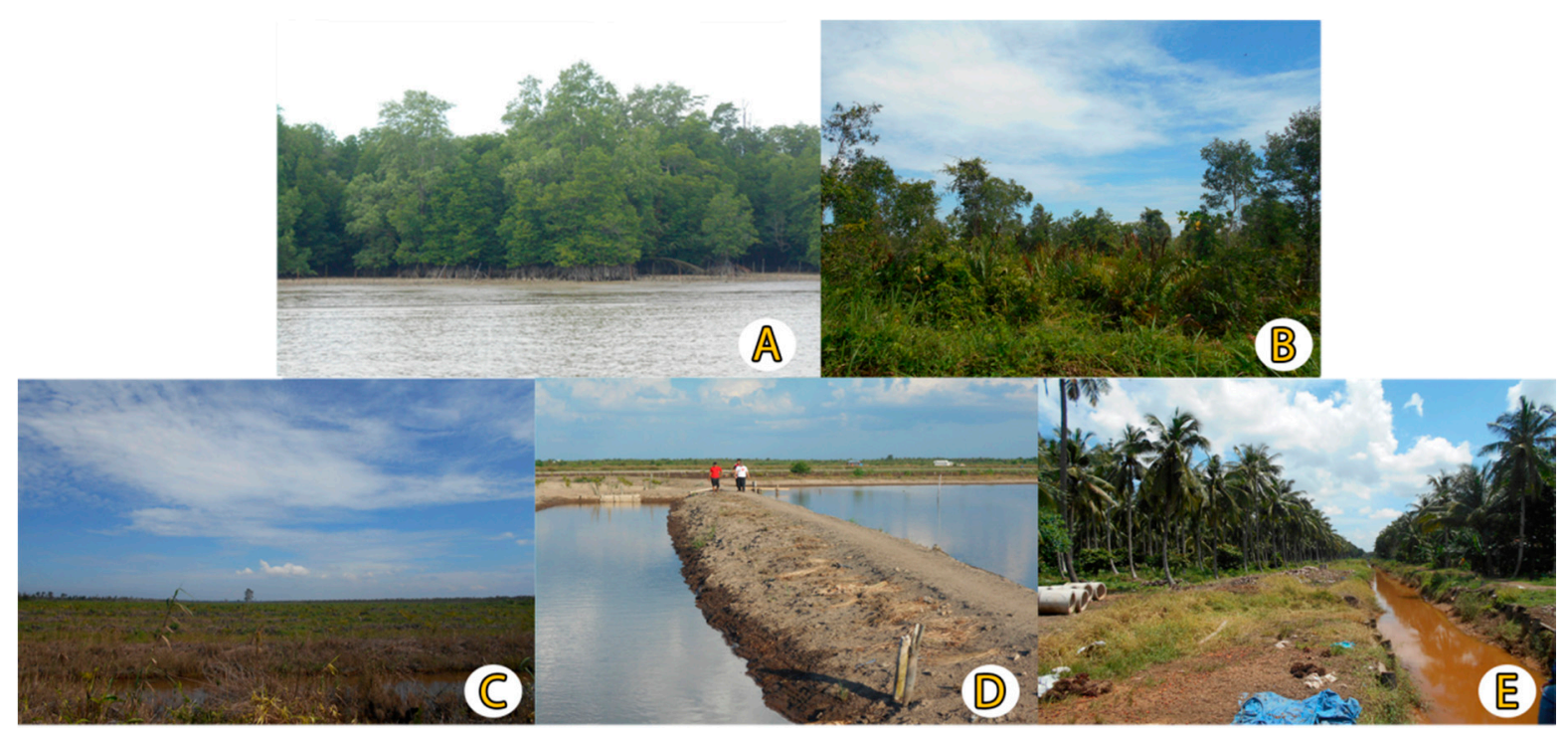

Figure 2. Conditions of land cover types in ATPF: (A) primary forest, (B) secondary forest, (C) open area, (D) fishpond, and (E) coconut plantation.

For the carbon emissions estimate, we used secondary data of the mangrove carbon stocks and emission factors for the coconut plantation and aquaculture from previously published studies by [29-32]. Specifically, carbon stocks for the primary mangrove forest were obtained from a previous study performed in Sembilang National Park, approximately $\sim 25 \mathrm{~km}$ from the ATPF [29]. Here, protected primary mangroves store approximately $1319 \pm 144 \mathrm{Mg} \mathrm{C} \mathrm{ha}^{-1}$ of the total ecosystem carbon stocks [29]. It is composed of $320 \pm 88$, $20 \pm 7$, and $979 \pm 152 \mathrm{Mg} \mathrm{C} \mathrm{ha}^{-1}$ of total biomass, woody debris, and soil carbon stock pools, respectively [29]. While there are no specific carbon stocks data available for the secondary mangrove forest, we assumed their total biomass carbon stocks represent $76 \%$ of the primary forests [33]. Moreover, we used a carbon stock loss fraction of $88 \%$ for the total biomass and $95 \%$ for the soil carbon pools following mangrove conversion to coconut plantation, as previously documented $[30,31]$ in the Philippines. Furthermore, carbon stock loss percentages of 83 and $52 \%$ for the total biomass and soil carbon losses, respectively, 
were used to calculate carbon stock loss due to aquaculture conversion, as reported in a global meta-analysis study [32].

\subsection{Data Analysis}

To link our analysis with an existing dataset, the official land cover category and definition were used and obtained from the national thematic map of the Ministry of Environment and Forestry of the Republic of Indonesia. The land cover type classification comprised primary forest, secondary forest, coconut plantation, open area, fishpond, and water body (Table 3 and Figure 2).

Table 3. Land cover types in ATPF and their respective characteristics.

\begin{tabular}{lll}
\hline \multicolumn{1}{c}{ Land Cover Types } & \multicolumn{1}{c}{ Characteristics } \\
\hline Primary mangrove forest & $\begin{array}{l}\text { Forests located in coastal areas are plains influenced by tides with muddy and } \\
\text { brackish soils. Plant species are dominated by mangrove and nipa (Nypa fruticans), } \\
\text { and are not or are slightly affected by human activities or logging. }\end{array}$ \\
\hline Secondary mangrove forest & $\begin{array}{l}\text { Forests located in coastal areas are plains that are affected by tides with muddy and } \\
\text { brackish soils. Plant species are dominated by mangrove and nipa (Nypa fruticans), } \\
\text { with visible logging activity. }\end{array}$ \\
\hline Coconut plantation & $\begin{array}{l}\text { Land used for agricultural activities without changing crops for two years, with a } \\
\text { dominance of coconut and oil palm plants. }\end{array}$ \\
\hline Open area/bare grounds & $\begin{array}{l}\text { Open area/bare ground and areas without vegetation, including sandbanks, sediment, } \\
\text { and post-fire areas. }\end{array}$ \\
\hline Fishpond/aquaculture & Areas used for aquaculture activities. \\
\hline Water body/open water & Open water in the form of rivers, lakes, and ponds. \\
\hline $\begin{array}{l}\text { MoEF. 2015. National Forest Reference Emission Level for Deforestation and Forest Degradation: In the Context of Decision 1/CP.16 } \\
\text { para 70 UNFCC (encourages developing country parties to contribute to mitigation actions in the forest sector) [33] and BSN. 2010. SNI }\end{array}$ & MoEF
\end{tabular}

We used the supervised classification method (visual interpretation) to perform image classification for all of the datasets. The visual interpretation method was an effective method for identifying land cover classifications [33]. While there was a spatial resolution difference between the Landsat and Sentinel products (Table 1), we used Landsat 8 image data acquired in 2020 to correct and adjust the land cover area generated by Sentinel-2 image data for the same year. This was done to improve the accuracy of the land cover classification results and to minimize the impact of the differences in the land use areas generated by all of the used datasets.

The land cover change detection analysis in ATPF was performed by overlaying the produced land cover maps between the periods studied. This technique is commonly used in remote sensing studies, and makes it possible to identify the extent of land cover changes between the given temporal period. The data analysis in this study was carried out using a Geographic Information System (GIS) with ArcGIS 10.5 software.

The estimation of the $\mathrm{CO}_{2}$ emissions in this study focused on emissions generated by mangrove conversion to other land uses, namely coconut plantations, fishponds, and open areas (deforestation). Overall, the $\mathrm{CO}_{2}$ emissions generated by each land use change between the analysis periods was estimated using the carbon stocks change approach [35]. First, we assumed that the initial carbon stocks of the primary mangrove cover in the first year of analysis were similar to the nearby mangrove forest reference in Sembilang National Park [29]. The initial carbon stocks in the secondary mangrove forests was $76 \%$ of the biomass carbon stock in the primary mangrove forests, which was previously reported in the national greenhouse gas inventory [33]. Subsequently, the carbon stock loss for each 
land use change was estimated by applying an emissions factor for the total biomass and soil carbon. The estimation of the $\mathrm{CO}_{2}$ emissions is described in Equation (1).

$$
\mathrm{CO}_{2} \text { emission }=44 / 12 \times \text { Carbon stock } \times \mathrm{EF} \times \text { LUC area }
$$

where the $\mathrm{CO}_{2}$ emission is the total $\mathrm{CO}_{2}$-eq emitted over the calculated land use change area, $44 / 12$ is the conversion factor of carbon stocks to $\mathrm{CO}_{2}$-eq, carbon stock is the initial carbon stock for each land use, EF is the percentage of carbon stock loss generated by each land use, and LUC area is the area of land use change between periods obtained from the change detection analysis. We excluded an uncertainty calculation in this study because of data availability limitations. A summary of the $\mathrm{CO}_{2}$ emission estimation for this study is provided in Supplementary Information Tables S1 and S2.

\section{Results}

\subsection{Mangrove Cover in 1985, 2000, and 2020}

Overall, six major land cover types were identified that most recently dominated ATPF, including primary forest, secondary forest, coconut plantation, open area, fishpond, and water body (Figure 3). According to the ground truth field data collection, the primary forest was dominated by true mangrove species, such as Nypa fruticans, Rhizophora apiculata, Sonneratia alba, Avicennia alba, Bruguiera cylindrica, Excoecaria agallocha, and Xylocarpus granatum, while the secondary forest was a mixture of mangrove stands and shrubs.
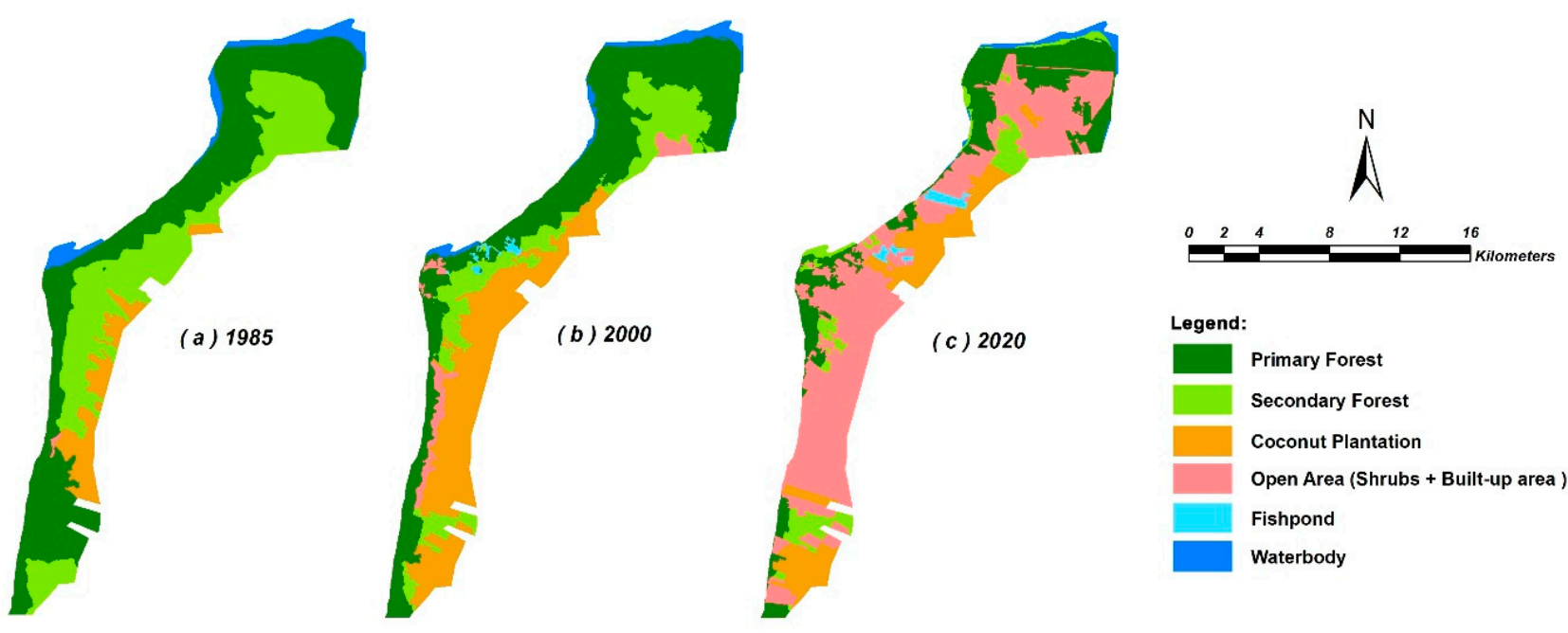

Legend:

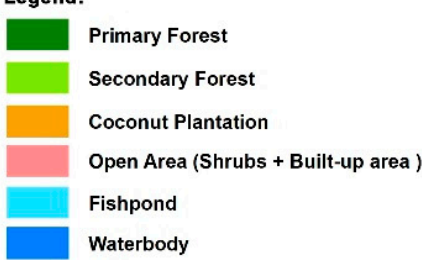

Figure 3. Land cover map in ATPF for (a) 1985, (b) 2000, and (c) 2020.

We observed that the area of both primary and secondary forests decreased significantly over the period of 35 years (1985-2020), as summarized in Table 4. In 1985, the primary forest was 6257 ha (49.42\% of total ATPF area), and after 35 years, the remaining primary mangrove forest area was only 2936 ha $(23.19 \%)$. This change indicates a substantial loss of primary forest of more than $50 \%$ over the mentioned period. Similarly, the area of the secondary forest was also reduced significantly from $36.56 \%$ in 1985 to only $8.87 \%$ in 2020. In contrast, we identified a significant increase in open area (deforested forest), of nearly $50 \%$, from the initial analysis year. Similarly, the coconut plantation area increased by $21 \%$ between $1985-2000$, but decreased by $15 \%$ between $2000-2020$. Finally, the fishpond area continued to increase during the entire analysis period of 1985-2020, despite the area of increase being only 189 ha or around $1.5 \%$ of the latest total ATPF area. 
Table 4. Area of land cover types in ATPF in 1985, 2000, and 2020.

\begin{tabular}{ccccccc}
\hline \multirow{2}{*}{ Land Cover Types } & \multicolumn{2}{c}{ Area in $\mathbf{1 9 8 5}$} & \multicolumn{2}{c}{ Area in $\mathbf{2 0 0 0}$} & \multicolumn{2}{c}{ Area in 2020 } \\
\cline { 2 - 6 } & ha & $\mathbf{\%}$ & ha & $\mathbf{\%}$ & ha & 2936.06 \\
Primary mangrove forest & 6257.00 & 49.42 & 5321.36 & 42.03 & 23.19 \\
Secondary mangrove forest & 4628.81 & 36.56 & 2563.83 & 20.25 & 1123.02 & 8.87 \\
Coconut plantation & 1074.91 & 8.49 & 3713.43 & 29.33 & 1834.56 & 14.49 \\
Open area/deforested area & 22.79 & 0.18 & 495.04 & 3.91 & 6334.23 & 50.03 \\
Fishpond & - & 0.00 & 93.69 & 0.74 & 189.91 \\
Waterbody & 677.36 & 5.35 & 473.52 & 3.74 & 243.09 & 1.50 \\
\hline Total & $12,660.87$ & 100.00 & $12,660.87$ & 100.00 & $12,660.87$ & 100.00 \\
\hline
\end{tabular}

Note: ha—area of land cover type in ha; \%—percentage area of land cover type of the total ATPF area.

\subsection{Land Cover Change 1985-2000 and 2000-2020}

During the first and second time periods, there was a decrease in the area of the primary forest by 935 and 2385 ha, respectively. During these same two time periods, secondary forests also experienced a decline of 2064 and 1440 ha, respectively (Figure 4). Coconut plantations expanded by 2638 ha over the 1985-2000 period, but decreased by 1878 ha over the 2000-2020 period (Figure 4). Similarly, the deforested area expanded by 1878 ha in the second period. The fishpond area increased in the two periods compared with only less than 100 ha or $1 \%$ in 35 years. Similarly, a reduction in the water body area also occurred in these two periods (Figure 4).

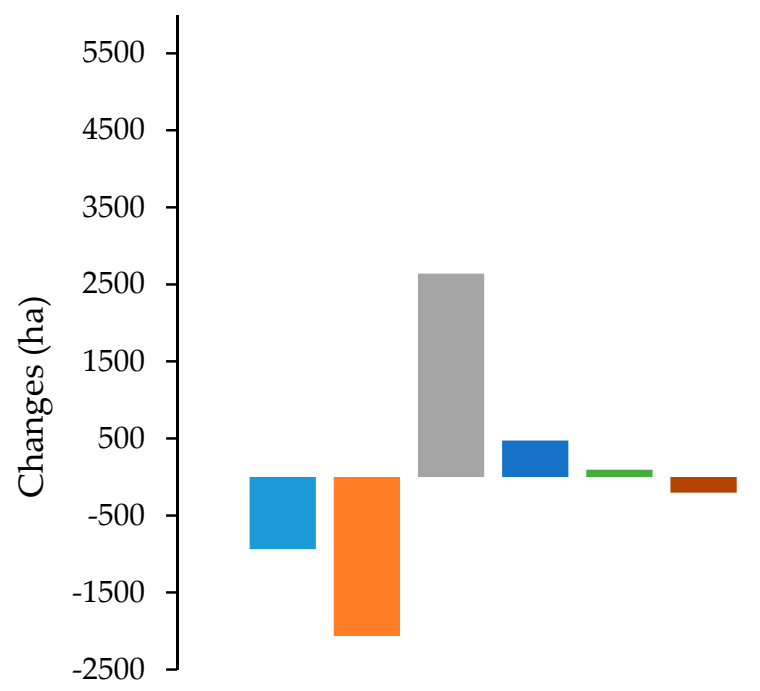

1985-2000

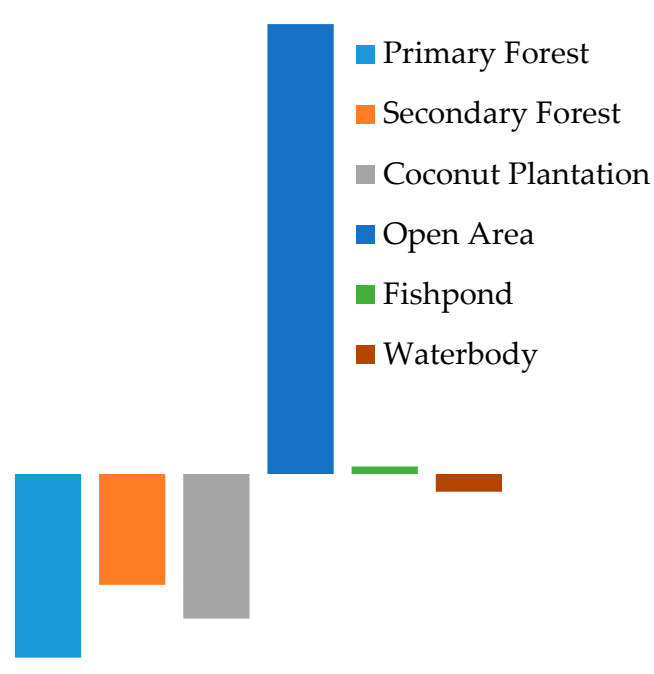

2000-2020

Period

Figure 4. Increase (positive change) and decrease (negative change) in the area of each type of land cover in ATPF during the period 1985-2000 and 2000-2020.

The land cover change analysis indicated that in the 1985-2000 period, primary and secondary mangrove forests were mostly converted to coconut plantations (Figure 5), with as much as 667 and 1970 ha, respectively. In the same timeframe, the degradation and conversion of primary forests into secondary forests and open areas were 361 and 178 ha, respectively. Additionally, only 66 ha of primary forest area was converted to fishponds. 


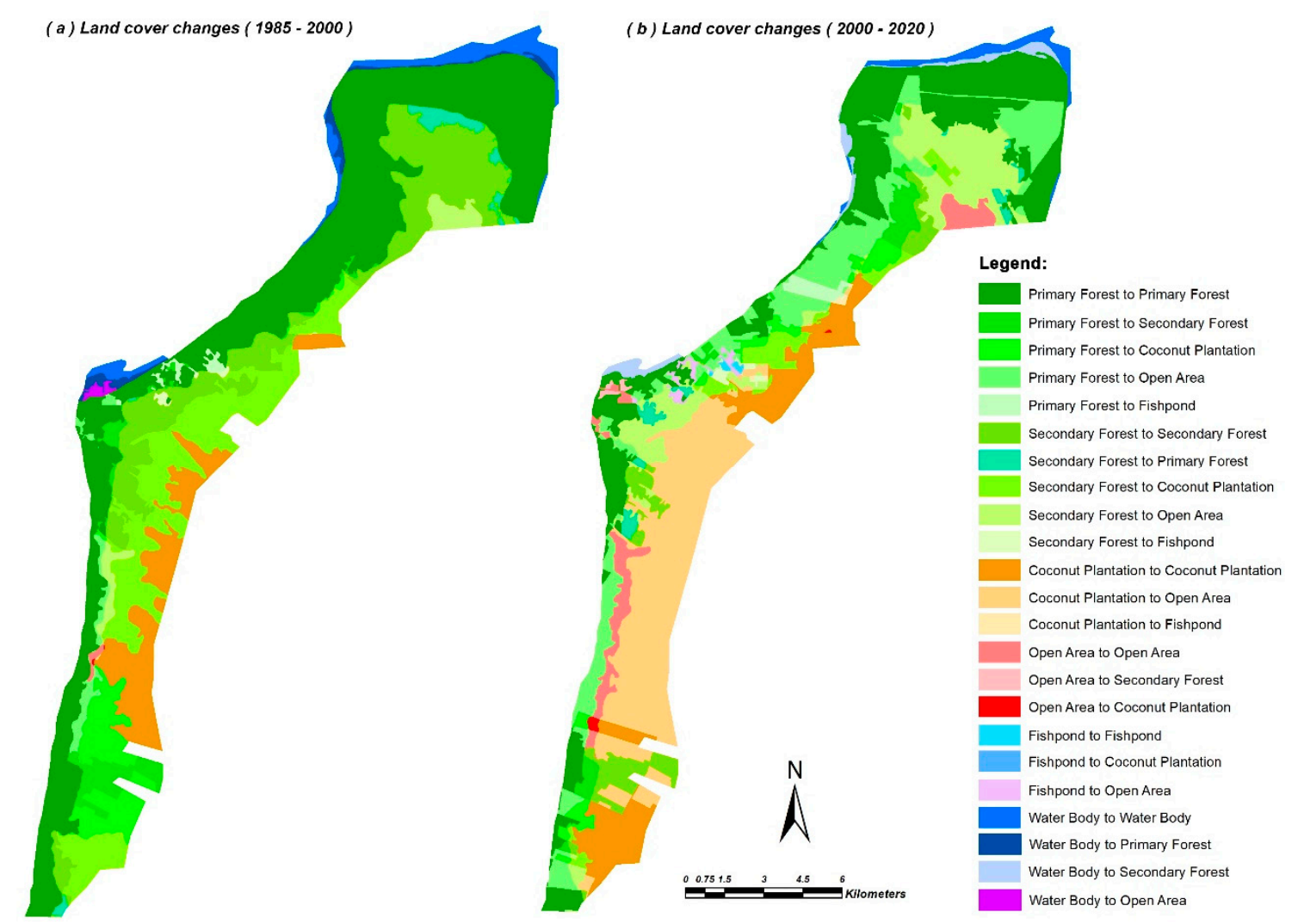

Figure 5. Map of land cover change in the ATPF 1985-2000 and 2000-2020 periods.

In the period of 2000-2020, both primary and secondary forests experienced the largest degradation and conversion into open areas or deforestation (Figure 5), by as much as 1844 and 1409 ha, respectively. Moreover, around 2556 ha of coconut plantations were also changed into open areas. In this second period, the conversion of primary forests to coconut plantations and fishponds were 290 and 110 ha, respectively. Meanwhile, the conversion of secondary forests into coconut plantations and fishponds were 386 and 40 ha, respectively.

\subsection{Carbon Emissions Generated by Mangrove Conversion to Other Land Uses}

Throughout 1985-2020, we observed that the largest mangrove loss in ATPF was driven by deforestation (3693 ha), followed by coconut plantations (3315 ha) and fishponds (245 ha; Figure 6 and Table 5). Coconut plantations were the primary mangrove loss driver before 2000, while deforestation largely occurred after 2000 (Figure 6a). However, we estimated the largest carbon emissions were from coconut plantation conversion throughout all of the analysis periods, with the total carbon emissions being approximately $14.14 \mathrm{Mt} \mathrm{CO}_{2}$-eq (Figure 6b). These amounts were almost four times higher than the emissions from deforestation, even though they impacted a larger area of mangrove loss (Figure 6). During 1985-2000 alone, mangrove conversion to coconut plantations generated the largest carbon emissions, around $11.23 \mathrm{Mt} \mathrm{CO}_{2}$-eq or $94 \%$ of the total emissions over this period. Moreover, the largest carbon emissions from mangrove deforestation were 3.42 Mt CO 2 -eq, occurring during 2000-2020. We observed a low area change impacted by fishpond development in ATPF throughout the analysis years. 
(a)

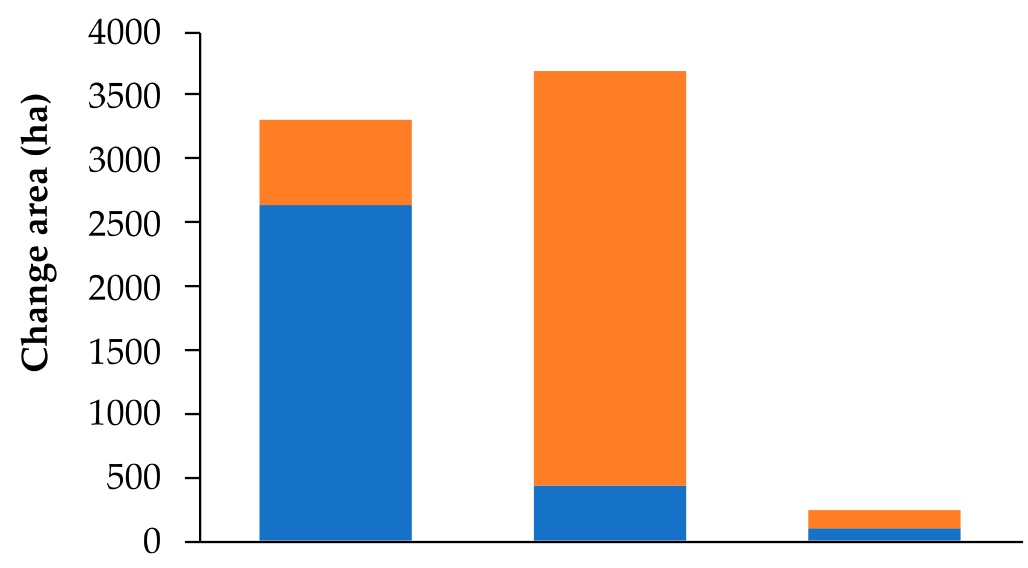

(b)

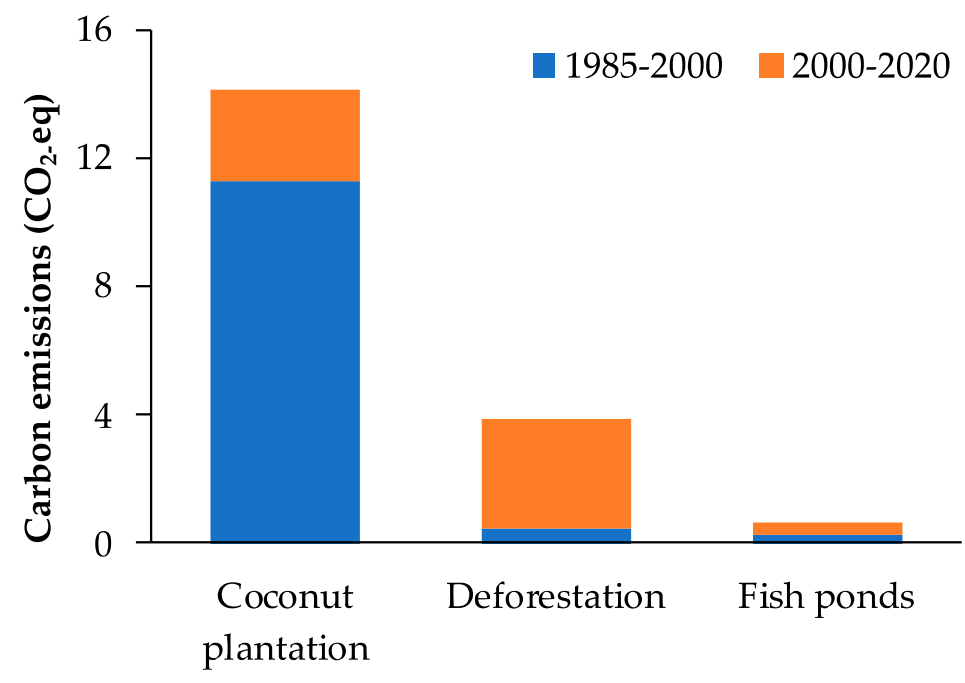

\section{Drivers of mangrove loss}

Figure 6. (a) Area of converted mangroves (combined primary and secondary forests) to other land uses, and (b) their associated carbon emissions, between 1985-2000 and 2000-2020.

Table 5. Quantitative land cover changes during the periods of 1985-2000 and 2000-2020.

\begin{tabular}{|c|c|c|c|c|c|c|c|}
\hline \multirow{2}{*}{$\begin{array}{l}\text { Land Cover Types } \\
\text { Period 1985-2000 }\end{array}$} & \multicolumn{7}{|c|}{ Land Cover Changes (ha) } \\
\hline & PMF & SMF & $\mathrm{CP}$ & $\mathrm{OA}$ & $\mathrm{Fp}$ & WB & Total \\
\hline PMF & 4983.23 & 361.86 & 667.13 & 178.29 & 66.49 & 0.00 & 6257.00 \\
\hline SMF & 168.38 & 2201.97 & 1970.81 & 260.45 & 27.20 & 0.00 & 4628.81 \\
\hline $\mathrm{CP}$ & 0.00 & 0.00 & 1072.97 & 1.94 & 0.00 & 0.00 & 1074.91 \\
\hline $\mathrm{OA}$ & 0.00 & 0.00 & 2.52 & 20.27 & 0.00 & 0.00 & 22.79 \\
\hline $\mathrm{Fp}$ & 0.00 & 0.00 & 0.00 & 0.00 & 0.00 & 0.00 & 0.00 \\
\hline WB & 169.75 & 0.00 & 0.00 & 34.09 & 0.00 & 473.52 & 677.36 \\
\hline Total & 5321.36 & 2563.83 & 3713.43 & 495.04 & 93.69 & 473.52 & $12,660.87$ \\
\hline Period 2000-2020 & PMF & SMF & $\mathrm{CP}$ & $\mathrm{OA}$ & $\mathrm{Fp}$ & WB & Total \\
\hline PMF & 2787.87 & 287.67 & 290.63 & 1844.22 & 110.97 & 0.00 & 5321.36 \\
\hline SMF & 148.19 & 579.17 & 386.18 & 1409.75 & 40.54 & 0.00 & 2563.83 \\
\hline $\mathrm{CP}$ & 0.00 & 0.00 & 1140.09 & 2556.61 & 16.73 & 0.00 & 3713.43 \\
\hline $\mathrm{OA}$ & 0.00 & 25.75 & 17.62 & 451.67 & 0.00 & 0.00 & 495.04 \\
\hline $\mathrm{FP}$ & 0.00 & 0.00 & 0.04 & 71.98 & 21.67 & 0.00 & 93.69 \\
\hline WB & 0.00 & 230.43 & 0.00 & 0.00 & 0.00 & 243.09 & 473.52 \\
\hline Total & 2936.06 & 1123.02 & 1834.56 & 6334.23 & 189.91 & 243.09 & $12,660.87$ \\
\hline
\end{tabular}

PM-primary mangrove forest; SMF—secondary mangrove forest; $\mathrm{CP}$-coconut plantation; $\mathrm{OA}$-open area; Fp—fishpond; WBwater body. 


\section{Discussion}

\subsection{Coconut Plantation as the Main Driver of Mangrove Loss in South Sumatra}

The degradation of mangrove forests in the ATPF over the past 35 years was driven by various anthropogenic activities, including coconut plantations, fishponds, settlements, and agriculture. Our findings are consistent with regional- and global-scale assessments, according to which anthropogenic activities such as land-use change ares the primary driver of mangrove loss $[15,17,25,36-46]$. Unlike other studies in the region that found aquaculture and oil palm plantations to be the dominant drivers of mangrove loss [36,46], we observed that coconut plantations were the second dominant driver in ATPF, after deforestation. This trend was also observed elsewhere in the Southeast Asia region, where coconut plantations also replaced some mangrove areas in the Philippines, with a substantial impact on reduced carbon stock [30,31]. According to the information from local communities, the coconut plantations ATPF began in 1972, which was promoted by the Bugis (Sulawesi) people who migrated to this area. Subsequently, most of the new coconut plantation areas were developed by replacing primary and secondary forests. Our findings suggest that coconut plantations are the new frontier of mangrove loss drivers, in addition to oil palm plantations, which were previously observed in the northern part of Sumatra [46].

We observed a large area of deforested mangroves or open area land cover type. According to the information from local communities obtained during fieldwork, this open area represents cleared lands owned by coastal communities and companies for various purposes, including the development of agricultural land and oil palm plantations. Additionally, this open area was also used to regrow coconut trees, following a rejuvenation program after more than 20 years of the first plantation. This is consistent with our findings of ATPF's land cover in 2000, according to which coconut plantations occupied approximately $50 \%$ of the total area of ATPF. Furthermore, we observed a low number of fishpond expansion in ATPF, despite the typical land use commonly observed replacing mangroves in Southeast Asia [46].

The area of both primary and secondary forests in ATPF continued to decline during the 1985-2020 period. Nevertheless, the remaining forest areas were dominated by Nypa fruticans, spanning across almost all coastline areas of ATPF [22,47]. The domination of invasive mangrove palms such as Nypa fruticans indicates that the areas are heavily disturbed in ATPF. Researchers usually consider this species as one of the biological indicators for mangrove forest disturbance [47-49].

\subsection{Carbon Emissions and Their Implication for Land Management and Restoration}

The estimated carbon emissions suggest that coconut plantations generated four times more carbon than those from deforestation, despite deforestation being the largest driver of mangrove loss area in ATPF during the past 35 years. Our findings are consistent with previous studies in the Philippines, where soil carbon loss was dominant because of the significant coastal landscape transformation [11,30,31]. Planting coconut trees in the cleared mangrove area requires drainage in order to avoid high salinity water following tidal inundation. A similar modification has also also observed for the development of oil palm plantations on top of mangrove forests [46]. Therefore, such belowground modification and drainage may lead to elevated soil organic matter oxidation and dissolved organic matter release through aquatic pathways, resulting in lowered soil carbon stocks.

Despite the fact that we estimated the carbon emissions from secondary data sources, our estimates suggest that mangrove conversion to other land uses could generate larger emissions than the forests that only experienced deforestation. This is consistent with previous studies documented elsewhere [32,50], suggesting that avoiding future mangrove loss and conversion could lead significant emission reductions from the land sector. Our findings could be a proxy for land managers and policy makers on how to improve land management in coastal mangrove area, specifically by promoting conservation and restoration programs to support national emission reduction targets, as outlined in the Nationally Determined Contributions (NDCs). 
Some restoration programs in ATPF have been started since 2011 by the government and community of Banyuasin Regency. However, land tenure seems to be a persisting issue, as the converted land is owned by many entities, including local communities and private sectors. This situation has led to the restoration programs being placed on hold over the past decade. Additionally, the restoration of degraded mangrove forests might require a substantial budget allocation in the long term. Mukherjee [10] stated that habitat degradation as a result of anthropogenic activities and development, both in developed and developing countries, requires a restoration time of more than 20 years. In addition, the success of the restoration is highly dependent on the commitment of state institutions and on community support. Policy failure and the dysfunction of state institutions, as well as a lack of participatory awareness and community commitment, can disrupt the restoration and conservation process [51].

While the carbon emissions estimate in this study could indicate the magnitude and variation of emissions between land uses, the use of secondary carbon stocks data and stocks-difference approach may lead to several limitations. First, the secondary carbon stocks data obtained in 2010 from Sembilang National Park mangroves [29] may not be similar with the ones in ATPF, particularly when we these data were to estimate stocks back in 1985 and 2010 (e.g., space for time substitution approach). Second, mangrove carbon stocks and fluxes are highly varied toward spatial hydrogeomorphic setting and temporal variability, respectively [52]. Estimating carbon stocks and emissions should therefore carefully consider the spatial replication of field sampling. Future similar studies may also consider the use of shorter temporal satellite imagery acquisition, such as every 5 years, rather than 15 or 20 years. This is particularly important, because of the extensive dynamics of aboveground biomass in mangrove forests, with recovery rates up to $4-7 \mathrm{MgC} \mathrm{ha}^{-1} \mathrm{yr}^{-1}$ [32]. Third, the singled-out emissions estimate using only the $\mathrm{CO}_{2}$ equivalent neglects other greenhouse gases (GHGs), particularly $\left(\mathrm{CH}_{4}\right)$ methane [53], as well as aquatic carbon export. Therefore, our approach contributes further uncertainty regarding unaccounted emissions from $\mathrm{CH}_{4}$ and aquatic components. While $\mathrm{CH}_{4}$ is 28 times more potent compared with $\mathrm{CO}_{2}$ [54], incorporating this GHG into future mangroverelated emission estimates will be essential in order to reduce uncertainty, specifically as it is reported that restoring and rewetting mangroves could generate higher $\mathrm{CH}_{4}$ emissions, despite lowering $\mathrm{CO}_{2}$ emissions [55].

\section{Conclusions}

We have identified that the land cover in the ATPF area is composed of primary forests, secondary forests, coconut plantations, open areas, fishponds, and water bodies. Our historical land use change reconstruction using remote sensing analysis further revealed that primary and secondary forest areas decreased continuously over a period of 35 years (1985-2020) in response to the aforementioned anthropogenic drivers. Specifically, we observed that the expansion of coconut plantations is the dominant driver for mangrove loss in South Sumatra, unlike most previous studies in Indonesia, in which mangroves were replaced by aquaculture ponds. We also observed that fishpond was one of the drivers for mangrove loss in the study site, but the number was insignificant. The estimated carbon emissions suggests that mangrove conversion to coconut plantation led a higher carbon emissions compared to other land use change, even though this land use was not the largest driver for mangrove loss in ATPF. Nevertheless, our carbon emissions estimate, which employed secondary data and simple back-in-envelope calculations, may generate some uncertainties and limitations, such as unaccounted emissions from other GHGs, as well as aquatic components. These limitations suggest that our findings and associated assumptions can be considered as a preliminary approach, therefore providing a complementary foundation for future studies on mangrove and associated land use emissions in the region. Overall, our findings imply that improved coastal land management with the avoidance of future mangrove loss is urgently required in order to support national efforts for reducing carbon emissions from the land sector. 
Supplementary Materials: The following are available online at https:/ /www.mdpi.com/1999-490 7/12/2/187/s1. Table S1: Summary of carbon stocks data in the Sembilang National Park used to estimate carbon emissions. Data are reported in the literature [29]. Table S2: Summary of emissions factor for mangrove conversion to coconut plantation, fishpond, and open area (forest clearing or deforestation); Table S3: Summary of carbon emissions calculation for each land use change and period. $\mathrm{PMF}$ - primary mangrove forest; $\mathrm{SMF}$ — secondary mangrove forest; $\mathrm{CP}$ — coconut plantation; $\mathrm{OA}$-open area; FP-fishpond.

Author Contributions: Conceptualization, S.E., N.M., and M.B.; methodology, S.E. and S.D.S.; validation, S.E., N.M., and M.B.; investigation, S.E.; resources, N.M.; data curation, S.E., N.M., S.D.S. writing—original draft preparation, S.E.; writing—review and editing, S.E., N.M., M.B., S.D.S., and T.K.; supervision, M.B., and T.K.; project administration, M.B.; funding acquisition, M.B. All authors have read and agreed to the published version of the manuscript.

Funding: This work was supported by the Directorate of Research and Community Service; the Ministry of Research and Technology; and the National Research and Innovation Agency, Republic of Indonesia, through the Post-Doctoral Research Scheme 2020 (No. 11/AMD/E1/KP.PTNB/2020). This study was also supported, in part, by the Directorate of Resources; the Directorate General of Higher Education; and the Ministry of Education and Culture, Republic of Indonesia, through World Class Professor Scheme B 2020 (No. 101.19/E4.3/KU/2020).

Data Availability Statement: The authors confirm that the data supporting the findings of this study are available within the article and/or its supplementary materials.

Conflicts of Interest: The authors declare no conflict of interest.

\section{References}

1. Bryan-Brown, D.N.; Connolly, R.M.; Richards, D.R.; Adame, F.; Friess, D.A.; Brown, C.J. Global trends in mangrove forest fragmentation. Sci. Rep. 2020, 10, 7117. [CrossRef] [PubMed]

2. Strauch, A.M.; Cohen, S.; Ellmore, G.S. Environmental Influences on the Distribution of Mangroves on Bahamas Island. J. Wetl. Ecol. 2012, 6, 16-24. [CrossRef]

3. Giri, C.; Ochieng, E.; Tieszen, L.L.; Zhu, Z.; Singh, A.; Loveland, T.; Masek, J.; Duke, N. Status and distribution of mangrove forests of the world using earth observation satellite data. Glob. Ecol. Biogeogr. 2011, 20, 154-159. [CrossRef]

4. Duke, N.C.; Ball, M.C.; Ellison, J.C. Factors influencing biodiversity and distributional gradients in mangroves. Glob. Ecol. Biogeogr. Lett. 1998, 7, 27-47. [CrossRef]

5. Basyuni, M.; Baba, S.; Kinjo, Y.; Putri, L.A.P.; Hakim, L.; Oku, H. Salt-dependent increase in triterpenoids is reversible upon transfer to fresh water in mangrove plants Kandelia candel and Bruguiera gymnorrhiza. J. Plant Physiol. 2012, 169, 1903-1908. [CrossRef] [PubMed]

6. $\quad$ Lee, S.Y.; Dunn, R.J.K.; Young, R.A.; Connolly, R.M.; Dale, P.E.R.; Dehayr, R.; Lemckert, C.J.; McKinnon, S.; Powell, B.; Teasdale, P.R.; et al. Impact of urbanization on coastal wetland structure and function. Austral Ecol. 2006, 31, 149-163. [CrossRef]

7. Fatoyinbo, T.E.; Simard, M.; Washington-Allen, R.A.; Shugart, H.H. Landscape-scale extent, height, biomass, and carbon estimation of Mozambique's mangrove, forests with Landsat ETM+ and Shuttle Radar Topography Mission elevation data. J. Geophys. Res. Biogeosci. 2008, 113, 1-13. [CrossRef]

8. Nagelkerken, I.; Blaber, S.J.M.; Bouillon, S.; Green, P.; Haywood, M.; Kirton, L.G.; Meynecke, J.O.; Pawlik, J.; Penrose, H.M.; Sasekumar, A.; et al. The habitat function of mangroves for terrestrial and marine fauna: A review. Aquat. Bot. 2008, 89, 155-185. [CrossRef]

9. Koch, E.W.; Barbier, E.B.; Silliman, B.R.; Reed, D.J.; Perillo, G.M.E.; Hacker, S.D.; Granek, E.F.; Primavera, J.H.; Muthiga, N.; Polasky, S.; et al. Non-linearity in ecosystem services: Temporal and spatial variability in coastal protection. Front. Ecol. Environ. 2009, 7, 29-37. [CrossRef]

10. Mukherjee, N.; Sutherland, W.J.; Khan, M.N.I.; Berger, U.; Schmitz, N.; Dahdouh-Guebas, F.; Koedam, N. Using expert knowledge and modeling to define mangrove composition, functioning, and threats and estimate time frame for recovery. Ecol. Evol. 2014, 4, 2247-2262. [CrossRef] [PubMed]

11. Atwood, T.B.; Connolly, R.M.; Almahasheer, H.; Carnell, P.E.; Duarte, C.M.; Lewis, C.J.E.; Irigoien, X.; Kelleway, J.J.; Lavery, P.S.; Macreadie, P.I.; et al. Global patterns in mangrove soil carbon stocks and losses. Nat. Clim. Chang. 2017, 7, 523-528. [CrossRef]

12. Ouyang, X.; Lee, S.Y.; Connolly, R.M.; Kainz, M.J. Spatially-explicit valuation of coastal wetlands for cyclone mitigation in Australia and China. Sci. Rep. 2018, 8, 1-9. [CrossRef]

13. Hochard, J.P.; Hamilton, S.; Barbier, E.B. Mangroves shelter coastal economic activity from cyclones. Proc. Natl. Acad. Sci. USA 2019, 116, 12232-12237. [CrossRef]

14. Dat, P.T.; Yoshino, K. Comparing Mangrove Forest Management in Hai Phong City, Vietnam towards Sustainable Aquaculture. Procedia Environ. Sci. 2013, 17, 109-118. [CrossRef] 
15. Komiyama, A. Conservation of Mangrove Ecosystems Through the Eyes of a Production Ecologist. Rev. Agric. Sci. 2014, 2, 11-20. [CrossRef]

16. Lovelock, C.E.; Cahoon, D.R.; Friess, D.A.; Guntenspergen, G.R.; Krauss, K.W.; Reef, R.; Rogers, K.; Saunders, M.L.; Sidik, F.; Swales, A.; et al. The vulnerability of Indo-Pacific mangrove forests to sea-level rise. Nature 2015, 526, 559-563. [CrossRef] [PubMed]

17. Nfotabong-Atheull, A.; Din, N.; Dahdouh-Guebas, F. Qualitative and Quantitative Characterization of Mangrove Vegetation Structure and Dynamics in a Peri-urban Setting of Douala (Cameroon): An Approach Using Air-Borne Imagery. Estuaries Coasts 2013, 36, 1181-1192. [CrossRef]

18. Schuerch, M.; Spencer, T.; Temmerman, S.; Kirwan, M.L.; Wolff, C.; Lincke, D.; McOwen, C.J.; Pickering, M.D.; Reef, R.; Vafeidis, A.T.; et al. Future response of global coastal wetlands to sea-level rise. Nature 2018, 561, 231-234. [CrossRef]

19. DasGupta, R.; Shaw, R. Cumulative Impacts of Human Interventions and Climate Change on Mangrove Ecosystems of South and Southeast Asia: An Overview. J. Ecosyst. 2013, 2013, 379429. [CrossRef]

20. Kusmana, C. Distribution and Current Status of Mangrove. In Mangrove Ecosystems of Asia; Faridah-Hanum, I., Latiff, A., Hakeem, K.R., Ozturk, M., Eds.; Springer: New York, NY, USA, 2014; pp. 37-60. ISBN 9781461485827.

21. Eddy, S.; Iskandar, I.; Ridho, M.R.; Mulyana, A. Land cover changes in the air telang protected forest, South Sumatra, Indonesia (1989-2013). Biodiversitas 2017, 18, 1538-1545. [CrossRef]

22. Eddy, S.; Ridho, M.R.; Iskandar, I.; Mulyana, A. Species composition and structure of degraded mangrove vegetation in the Air Telang Protected Forest, South Sumatra, Indonesia. Biodiversitas 2019, 20, 2119-2127. [CrossRef]

23. Mai, N.T.H.; Tan, N.Q.; Linh, N.H.K. Understanding the Status and Challenges of Mangrove Conservation in Central Vietnam: Case Study in Duy Xuyen District, Quang Nam Province. Hue Univ. J. Sci. Agric. Rural Dev. 2019, 128, 71-83. [CrossRef]

24. Kairo, J.G.; Dahdouh-Guebas, F.; Bosire, J.; Koedam, N. Restoration and management of mangrove systems-A lesson for and from the East African region. S. Afr. J. Bot. 2001, 67, 383-389. [CrossRef]

25. Pham, T.D.; Yokoya, N.; Bui, D.T.; Yoshino, K.; Friess, D.A. Remote sensing approaches for monitoring mangrove species, structure, and biomass: Opportunities and challenges. Remote Sens. 2019, 11, 230. [CrossRef]

26. Li, M.S.; Mao, L.J.; Shen, W.J.; Liu, S.Q.; Wei, A.S. Change and fragmentation trends of Zhanjiang mangrove forests in southern China using multi-temporal Landsat imagery (1977-2010). Estuar. Coast. Shelf Sci. 2013, 130, 111-120. [CrossRef]

27. Jayanth, J.; Ashok Kumar, T.; Koliwad, S.; Krishnashastry, S. Identification of land cover changes in the coastal area of Dakshina Kannada district, South India during the year 2004-2008. Egypt. J. Remote Sens. Sp. Sci. 2016, 19, 73-93. [CrossRef]

28. Nguyen, H.H.; Tran, L.T.N.; Le, A.T.; Nghia, N.H.; Duong, L.V.K.; Nguyen, H.T.T.; Bohm, S.; Premnath, C.F.S. Monitoring changes in coastal mangrove extents using multi-temporal satellite data in selected communes, Hai Phong City, Vietnam. For. Soc. 2020, 4, 256-270. [CrossRef]

29. Murdiyarso, D.; Purbopuspito, J.; Kauffman, J.B.; Warren, M.W.; Sasmito, S.D.; Donato, D.C.; Manuri, S.; Krisnawati, H.; Taberima, S.; Kurnianto, S. The potential of Indonesian mangrove forests for global climate change mitigation. Nat. Clim. Chang. 2015, 5, 1089-1092. [CrossRef]

30. Castillo, J.A.A.; Apan, A.A.; Maraseni, T.N.; Salmo, S.G., III. Estimation and mapping of above-ground biomass of mangrove forests and their replacement land uses in the Philippines using Sentinel imagery. ISPRS J. Photogramm. Remote Sens. 2017, 134, 70-85. [CrossRef]

31. Castillo, J.A.A.; Apan, A.A.; Maraseni, T.N.; Salmo, S.G., III. Soil C quantities of mangrove forests, their competing land uses, and their spatial distribution in the coast of Honda Bay, Philippines. Geoderma 2017, 293, 82-90. [CrossRef]

32. Sasmito, S.D.; Taillardat, P.; Clendenning, J.N.; Cameron, C.; Friess, D.A.; Murdiyarso, D.; Hutley, L.B. Effect of land-use and land-cover change on mangrove blue carbon: A systematic review. Glob. Chang. Biol. 2019, 25, 4291-4302. [CrossRef] [PubMed]

33. MoEF (Ministry of Environment and Forestry). National Forest Reference Emission Level for Deforestation and Forest Degradation: In the Context of Decision 1/CP.16 para 70 UNFCCC (Encourages Developing Country Parties to Contribute to Mitigation Actions in the Forest Sector); Directorate General of Climate Change; The Ministry of Environment and Forestry: Jakarta, Indonesia, 2015; ISBN 9786027306615.

34. Badan Standarisasi Nasional. SNI 7645:2010 Klasifikasi Penutup Lahan; BSN: Jakarta, Indonesia, 2010.

35. IPCC. IPCC Guidelines for National Greenhouse Gas Inventories; Institute for Global Environmental Strategies: Hayama, Japan, 2006; Volume 5.

36. Ilman, M.; Wibisono, I.T.C.; Suryadiputra, I.N.N. State of the Art Information on Mangrove Ecosystems in Indonesia; Wetlands International-Indonesia Programme: Bogor, Indonesia, 2011. [CrossRef]

37. Donders, T.H.; Gorissen, P.M.; Sangiorgi, F.; Cremer, H.; Wagner-Cremer, F.; McGee, V. Three-hundred-year hydrological changes in a subtropical estuary, Rookery Bay (Florida): Human impact versus natural variability. Geochem. Geophys. Geosyst. 2008, 9. [CrossRef]

38. Giri, C.; Zhu, Z.; Tieszen, L.L.; Singh, A.; Gillette, S.; Kelmelis, J.A. Mangrove forest distributions and dynamics (1975-2005) of the tsunami-affected region of Asia. J. Biogeogr. 2008, 35, 519-528. [CrossRef]

39. Thu, P.M.; Populus, J. Status and changes of mangrove forest in Mekong Delta: Case study in Tra Vinh, Vietnam. Estuar. Coast. Shelf Sci. 2007, 71, 98-109. [CrossRef]

40. Bryan, J.E.; Shearman, P.L.; Asner, G.P.; Knapp, D.E.; Aoro, G.; Lokes, B. Extreme Differences in Forest Degradation in Borneo: Comparing Practices in Sarawak, Sabah, and Brunei. PLoS ONE 2013, 8, e69679. [CrossRef] 
41. Eddy, S.; Ridho, M.; Iskandar, I.; Mulyana, A. Community-Based Mangrove Forests Conservation for Sustainable Fisheries. J. Silvikultur Trop. 2016, 7, S42-S47. [CrossRef]

42. Giri, C.; Long, J.; Abbas, S.; Murali, R.M.; Qamer, F.M.; Pengra, B.; Thau, D. Distribution and dynamics of mangrove forests of South Asia. J. Environ. Manag. 2014, 148, 101-111. [CrossRef]

43. Jones, T.G.; Ratsimba, H.R.; Ravaoarinorotsihoarana, L.; Cripps, G.; Bey, A. Ecological segregation of the late jurassic stegosaurian and iguanodontian dinosaurs of the morrison formation in north america: Pronounced or subtle? Forests 2014, 5, 177-205. [CrossRef]

44. Sannigrahi, S.; Zhang, Q.; Pilla, F.; Joshi, P.K.; Basu, B.; Keesstra, S.; Roy, P.S.; Wang, Y.; Sutton, P.C.; Chakraborti, S.; et al. Responses of ecosystem services to natural and anthropogenic forcings: A spatial regression based assessment in the world's largest mangrove ecosystem. Sci. Total Environ. 2020, 715, 137004. [CrossRef]

45. Satyanarayana, B.; Mulder, S.; Jayatissa, L.P.; Dahdouh-Guebas, F. Are the mangroves in the Galle-Unawatuna area (Sri Lanka) at risk? A social-ecological approach involving local stakeholders for a better conservation policy. Ocean Coast. Manag. 2013, 71, 225-237. [CrossRef]

46. Richards, D.R.; Friess, D.A. Rates and drivers of mangrove deforestation in Souteast Asia, 2000-2012. Proc. Natl. Acad. Sci. USA 2016, 113, 344-349. [CrossRef]

47. Eddy, S.; Basyuni, M. The phenomenon of nipah (Nypa fruticans) invasion in the Air Telang Protected Forest, Banyuasin District, South Sumatra, Indonesia. Biodiversitas 2020, 21, 5114-5118. [CrossRef]

48. Shah, K.; Mustafa Kamal, A.H.; Rosli, Z.; Hakeem, K.R.; Hoque, M.M. Composition and diversity of plants in Sibuti mangrove forest, Sarawak, Malaysia. Forest Sci. Technol. 2016, 12, 70-76. [CrossRef]

49. Kassim, Z.; Ahmad, Z.; Ismail, N. Diversity of bivalves in mangrove forest, Tok Bali Kelantan, Malaysia. Sci. Herit. J. 2018, 2, 4-9. [CrossRef]

50. Pendleton, L.; Donato, D.C.; Murray, B.C.; Crooks, S.; Jenkins, W.A.; Sifleet, S.; Craft, C.; Fourqurean, J.W.; Kauffman, J.B.; Marbà, $\mathrm{N}$; et al. Estimating global "blue carbon" emissions from conversion and degradation of vegetated coastal ecosystems. PLoS ONE 2012, 7, e43542. [CrossRef]

51. Mangora, M.M. Poverty and institutional management stand-off: A restoration and conservation dilemma for mangrove forests of Tanzania. Wetl. Ecol. Manag. 2011, 19, 533-543. [CrossRef]

52. Sasmito, S.D.; Sillanpää, M.; Hayes, M.A.; Bachri, S.; Saragi-Sasmito, M.F.; Sidik, F.; Hanggara, B.B.; Mofu, W.Y.; Rumbiak, V.I.; Taberima, S.; et al. Mangrove blue carbon stocks and dynamics are controlled by hydrogeomorphic settings and land-use change. Glob. Chang. Biol. 2020, 26, 3028-3039. [CrossRef]

53. Lovelock, C.E.; Atwood, T.; Baldock, J.; Duarte, C.M.; Hickey, S.; Lavery, P.S.; Masque, P.; Macreadie, P.I.; Ricart, A.M.; Serrano, O.; et al. Assessing the risk of carbon dioxide emissions from blue carbon ecosystems. Front. Ecol. Environ. 2017, 15, 257-265. [CrossRef]

54. Myhre, G.; Shindell, D.; Bréon, F.-M.; Collins, W.; Fuglestvedt, J.; Huang, J.; Koch, D.; Lamarque, J.-F.; Lee, D.; Mendoza, B.; et al. Anthropogenic and Natural Radiative Forcing. In Climate Change 2013: The Physical Science Basis; Contribution of Working Group I to the Fifth Assessment Report of the Intergovernmental Panel on Climate Change; Stocker, T.F., Qin, D., Plattner, G.-K., Tignor, M., Allen, S.K., Boschung, J., Nauels, A., Xia, Y., Bex, V., Midgley, P.M., Eds.; Cambridge University Press: Cambridge, UK; New York, NY, USA, 2013.

55. Kroeger, K.D.; Crooks, S.; Moseman-Valtierra, S.; Tang, J. Restoring tides to reduce methane emissions in impounded wetlands: A new and potent blue carbon climate change intervention. Sci. Rep. 2017, 7, 11914. [CrossRef] [PubMed] 